\title{
CONSERVATION ASSESSMENT AND SPATIAL DISTRIBUTION OF ENDEMIC ORCHIDS IN SABAH, BORNEO
}

\author{
Suzika Juiling,"*, Scholena Kinit Leon', Jamirus Jumian², Sandy Tsen ${ }^{1,2}$, Yew Leung Lee', \\ Eyen Khoo ${ }^{2}$, John B. Sugau², Reuben Nilus², Joan T. Pereira², Alviana Damit ${ }^{2}$, \\ Sasikumar Tanggaraju ${ }^{1}$, Peter O’Byrne ${ }^{3, \dagger}$, Sukaibin Sumail ${ }^{4}$, Handry Mujih ${ }^{4}$, Colin R. Maycock ${ }^{1}$ \\ ${ }^{1}$ Universiti Malaysia Sabah, Malaysia \\ e-mail:*suzikajuiling@gmail.com,tsensandy@gmail.com,yewleung@gmail.com, \\ bs14161036@alum.ums.edu.my,colinr@ums.edu.my \\ ${ }^{2}$ Sabah Forestry Department, Malaysia \\ e-mail: gmirus4@gmail.com, biodipterocarp@gmail.com,john.sugau@sabah.gov.my, \\ rnilus70@gmail.com,joan.pereira18@gmail.com,Alviana.Damit@sabah.gov.my \\ ${ }^{3}$ Sabah, Malaysia \\ e-mail:oberonia@gmail.com \\ ${ }^{4}$ Sabah Parks, Malaysia \\ e-mail:skybyn@gmail.com,hanrymujih@gmail.com
}

Received: 15.04.2020. Revised: 12.07.2020. Accepted: 25.08.2020.

\begin{abstract}
Orchids are among the most threatened plants due to habitat loss and illegal harvesting for horticultural demands. Sabah is a centre of orchid diversity, with approximately 1300 species of which 250 orchid taxa are endemic to Sabah. In this study, we conducted an IUCN Red List assessment on 136 endemic species and used Maximum Entropy (MaxEnt) to develop species distribution models for 47 species. The species distribution models were developed using presence-only data and six environmental predictors. The accuracy of the models were assessed using the area under the curve (AUC) and models with an AUC of higher than 0.8 stacked together to produce a species richness heatmap. We found that $83 \%$ of the researched species were threatened, of which 14 species were assessed to be Critically Endangered, eight species as Endangered and 93 species as Vulnerable. The heatmap shows that all of the species occurred within the Totally Protected Area (TPA) network in western Sabah. The heatmap highlighted the mid-altitude areas adjacent to the Kinabalu and Crocker Range parks and Ulu Sipitang regions as areas with a high species richness that were outside the TPA network. These areas are also important for the conservation of the majority of the species assessed as Critically Endangered and Endangered. Urgent conservation actions are needed to protect these species from extinction. The results from this work will be used as part of an intensive conservation action plan for threatened endemic orchids of Sabah and used to identify important plant areas currently not within the existing TPA network.
\end{abstract}

Key words: habitat loss, illegal harvesting, IUCN Red List status, MaxEnt, Orchidaceae, Protected Area, species distribution modelling, species richness

\section{Introduction}

Loss of plant diversity is a major global concern (Jackson \& Kennedy, 2009). Land use change is the major cause of plant diversity loss, especially in the wet tropics (Giam et al., 2010; Brummitt et al., 2015; Corlett, 2016). High rates of forest loss coupled with high levels of biodiversity can lead to the loss of many plant species (Giam et al., 2010). As a response to this extinction crisis, the global community has called for actions to halt the current and continuing loss of plant diversity (Jackson \& Kennedy, 2009). Assessing which species are most at risk of extinction and identifying priority areas for plant protection are an integral part of this approach (Callmander et al., 2005).

The Orchidaceae is one of the largest families of flowering plants and contains ca. 30000 species (Hassler \& Rheinheimer, 2020). Their distinctive flowers make them popular among collectors and prone to overcollecting (Lamb, 1991a; Vermeulen \& Lamb, 2011; Ballantyne \& Pickering, 2012). Orchids are also sensitive to habitat loss and disturbance (Wraith \& Pickering, 2018). As most orchids are epiphytic and their existence depends on the availability of suitable host plants, this makes them susceptible to forest loss (Lamb, 1991a; Hietz, 1999). Despite being among the most threatened plants, only $5 \%$ of the world's orchids are listed on the IUCN Red List of Threatened Species (Fay, 2018; IUCN, 2020).

The island of Borneo is one of the centres of orchid diversity (Hassler \& Rheinheimer, 2020). The estimated number of orchid species in Borneo varied widely. Past estimates suggest that there were between 1400 and 3000 orchid species in Borneo (Lamb, 1991b; Wood \& Cribb, 1994). However, the most recent figure suggests about 1700 species, of which more than 1000 species are endemic to the island (Hassler \& Rheinheimer, 
2020). Within Borneo, the Malaysian State of Sabah has the richest orchid flora with an estimated 1300 species, of which approximately 250 species are endemic to Sabah (Sabah Forestry Department, unpublished data). This high species richness is partially related to the presence of Mount Kinabalu, the highest mountain in the Malay Archipelago. Mount Kinabalu is one of the global hotspots for plant diversity, and more than 860 orchid species have been recorded from the mountain (Ent, 2013).

Over the last forty years, Sabah has lost 39.5\% of its forest cover (Gaveau et al., 2014). Much of the remaining forest has been selectively logged, with only $19.1 \%$ of the remaining forest considered intact (Gaveau et al., 2014). How these disturbances affected the plant diversity of Sabah is only just starting to be understood. Currently, only $11 \%$ of the estimated 8000 plant species in Sabah have a Red List assessment and only eight of ca. 250 orchid species endemic to Sabah are listed on the IUCN Red List (IUCN, 2020). This study aims to 1) assess the threat status of the endemic orchids of Sabah using the IUCN Red List Categories and Criteria (Version 3.1), and 2) develop species distribution models (SDMs) using Maximum Entropy (MaxEnt) to identify their potential distribution across Sabah. As Sabah is in the process of increasing its Totally Protected Area (TPA) to $30 \%$ of Sabah's area (Williams et al., 2020), these SDMs will be used to identify areas with a high species richness of endemic orchids that are currently outside of Sabah's Protected Area network.

\section{Study site}

\section{Material and Methods}

Sabah is located in the northern part of Borneo $\left(05.420278^{\circ} \mathrm{N}, 116.796667^{\circ} \mathrm{E}\right.$, Fig. 1). It has a total land area of $73371 \mathrm{~km}^{2}$, accounting for approximately $10 \%$ of Borneo's total land area (Marsh \& Greer, 1992). In Sabah, the altitude ranges from sea level up to 4095 m a.s.l., with Mount Kinabalu being the highest point. The average annual temperature varies between $32^{\circ} \mathrm{C}$ in the lowlands and $21^{\circ} \mathrm{C}$ in the highlands. The mean annual rainfall is between $2500 \mathrm{~mm}$ and $3500 \mathrm{~mm}$, with the highest rainfall occurring in the mountainous areas of Mount Kinabalu and the Crocker Range. Fiftyone distinct soil associations have been described based on differences in soil texture, nutrient availability and drainage (Acres et al., 1975). These variations in climate, altitude and soils factors interact and determine the vegetation structure and diversity (Ashton \& Hall, 1992; Chan et al., 1994), with nineteen distinct floristics associations recognised within the State of Sabah (Sabah Forestry Department, 2004). The lowland and upland areas with well drained and moderately fertile to fertile soils are dominated by mixed dipterocarp forests. Kerangas (heath) forests are found on areas with podzolic soils in the lowland, upland and montane regions. Freshwater swamp and peat swamp forests occur in the lowland on soils with an impeded drainage. Ultramafic forests are found on serpentine soils. These soils have high concentrations of iron and nickel and low concentrations of plant nutrients (Chan et al., 1994; Proctor, 2003). Lower montane forests occur on the moderate fertile soils at altitudes higher than $1000 \mathrm{~m}$ a.s.1.. This transition to upper montane forest occurs at ca. $2500 \mathrm{~m}$ a.s.l. It is replaced by a sub-alpine vegetation at altitudes higher than $3500 \mathrm{~m}$ a.s.1. on the upper reaches of Mount Kinabalu (Sabah Forestry Department, 2004). These different floristic associations give rise to a diverse orchid flora. Terrestrial orchids such as Calanthe R. Br., Claderia Hook. f., Arundina Blume, Bromheadia Lindl., and Phaius Lour. are mostly found in lowland mixed dipterocarp forest near streams and on exposed ridges. The dense canopy layers of the dipterocarp forest favours epiphytic orchids such as Phalaenopsis Blume, Bulbophyllum Thouars and Coelogyne Lindl. The orchid flora is less diverse on the nutrient-poor soil of the Kerangas and Ultramafic forests. However, most orchids found in these areas are endemic to these habitats (Chan et al., 1994). High endemism also occurs in the montane regions due to different climatic zones and a habitat that restrict orchid distribution (Wood et al., 1993).

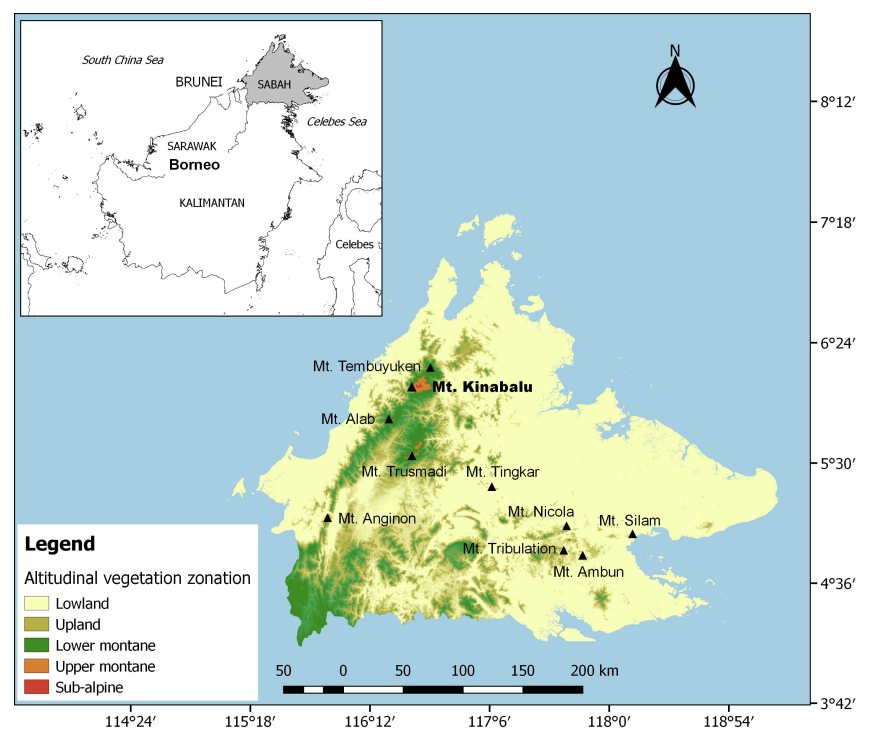

Fig. 1. A map showing the vegetation zonation on the basis of the altitudinal range with several key mountains in Sabah. 


\section{Data compilation}

To determine the conservation status and develop species distribution models for the endemic orchids of Sabah, we gathered data from the local herbaria (Sandakan Herbarium and Kinabalu Park Herbarium), living collections (Kipandi Butterfly Farm, Tenom Agricultural Park, Rainforest Discovery Centre and Poring Orchid Garden), the Global Biodiversity Information Facility (GBIF), and literature (Chan et al., 1994; Vermeulen, 1994; Wood, 1997, 2003, 2010; Wood et al., 2011; O'Byrne, 2016). Species information including the locality data were extracted and stored in a database (Chapman \& Wieczorek, 2006). Species occurrences without co-ordinates were georeferenced following the standard GBIF georeferencing protocols (Chapman \& Wieczorek, 2006) using a combination of topographic maps, soil maps for Sabah (Acres et al., 1975), the Sabah gazetteer (Tangah \& Wong, 1995), Mapcarta, Google Earth and Map of Mount Kinabalu (Beaman et al., 2003). The georeferenced datasets were used to produce a conservation assessment for the species, and a species distribution model was generated for species with more than five data points after data cleaning.

\section{Conservation assessment}

We used the IUCN Red List Categories and Criteria (Version 3.1) to assess the threat status for each species (IUCN Standards and Petitions Committee, 2019). The datasets were imported into the open source website Geospatial Conservation Assessment Tool (GeoCAT: http://geocat.kew.org) and an initial Area of Occupancy (AOO) and Extent of Occurrence (EOO) calculated for each species (Bachman et al., 2011). The EOOs were measured using a minimum convex polygon for species with at least three occurrences localities, and the AOOs were calculated using a $2 \mathrm{~km} \times 2 \mathrm{~km}$ grid (cell area: $4 \mathrm{~km}^{2}$ ) overlaid on each occurrence locality (IUCN Standards and Petitions Committee, 2019). To estimate habitat loss, we performed a reduction analysis by removing collection localities that no longer have a natural vegetation cover. The species were then assigned to a threat category based on this information after a group discussion by members of the Sabah Plant Red List working group. All members of this group have completed at least one IUCN Red List training course.

\section{Species distribution modelling (SDM)}

To reduce potential collection biases, we cleaned the datasets before modelling. Data cleaning involved removing points that were less than $2 \mathrm{~km}$ apart, except where the points occurred on different soil types, or were separated by more than $300 \mathrm{~m}$ in altitude (Frazier et al., 2004; Williams et al., 2020). For species with more than five collection localities after data cleaning, we modelled their distributions using MaxEnt (Version 3.4.1: https://www.cs.princeton.edu/ schapire/ maxent/). We used a mixture of bioclimatic, altitude and edaphic layers as predictor variables to generate the SDMs. The bioclimatic data was obtained from WorldClim (https://www.worldclim.org/), the altitude data from the STRM DEM (http://srtm.csi.cgiar.org) and the edaphic layers from the Soils of Sabah maps (Acres et al., 1975). All layers were standardised at 6 arc second resolution (Maycock et al., 2012).

We generated SDMs using the presence-only data and selected environmental variables. The layers included the annual mean temperature, annual precipitation, precipitation of the wettest month, and precipitation of driest month, soil associations and altitude. We ran MaxEnt using the cross validate function with ten replicate runs and 10000 random background points used as pseudo-absence. A detailed description of the modelling approach can be found in Williams et al. (2020). Model accuracy was evaluated using the area under the receiver operating characteristic curve (AUC) generated from the test data. This is a commonly used metric and generally accepted for model evaluation (Merow et al., 2013). All SDMs with an AUC of more than 0.8 value were retained and converted from logistic format to a presence-absence model using the Maximum training sensitivity plus specificity logistic threshold. The SDMs were then stacked in DIVA GIS to create a heatmap to show areas with high species richness of endemic orchids.

\section{Results \\ Conservation status}

A total of 136 species out of about 250 endemic orchid species in Sabah were assessed, of which about $83 \%$ are threatened (Fig. 2; Electronic Supplement 1). The majority of species $(67 \%)$ were assigned to the Vulnerable D2 category based on having an $\mathrm{AOO}$ of less than $20 \mathrm{~km}^{2}$ or number of locations $\leq 5$, and a potential threat that could drive them to a higher threat category. Twenty-two species were assigned to higher threat categories (Critically Endangered and Endangered) primarily due to a restricted distribution and a continuing decline in suitable habitat (Table 1; Electronic Supplement 1). Five species (Aerides sukauensis Shim, Appendicula clemensiorum J.J.Wood, Bulbophyllum cerebellum J.J.Verm., B. elachanthe J.J.Verm., and Zeuxine papillosa Carr) were assessed as Data Deficient due to a lack of recent collections and uncertainties associated with the original collection localities. 
Table 1. List of Sabah endemic orchids assessed as Critically Endangered (CR) and Endangered (EN)

\begin{tabular}{lll}
\hline \multicolumn{1}{c}{ Taxon name } & Category & Criteria \\
\hline Ascidieria caricifolia var. glabra (J.J.Wood) J.J.Wood & CR & B2ab(ii,iii) \\
Bulbophyllum alatum J.J.Verm. & CR & A2c \\
Bulbophyllum apheles J.J.Verm. & EN & B2ab(i,ii,iii,iv) \\
Bulbophyllum brachyrhopalon J.J.Verm., P.O'Byrne \& A.L.Lamb & CR & B2ab(iii) \\
Bulbophyllum nabawanense J.J.Wood \& A.L. Lamb & EN & B2ab(i,ii,iii,iv) \\
Bulbophyllum porphyrotriche J.J.Verm. & CR & B2ab(iii) \\
Bulbophyllum scabrum J.J.Verm. \& A.L.Lamb & EN & A2c \\
Bulbophyllum sigmoideum Ames \& C.Schweinf. & EN & A2c \\
Dendrobium cyrilianum P.O'Byrne, Gokusing \& J.J.Wood. & EN & B2ab(ii,iii,iv) \\
Dendrobium paitanense J.J.Wood & CR & B2ab(iii) \\
Dendrobium pseudoclavator J.J.Wood & CR & B2ab(iii) \\
Dendrobium tomaniense J.J.Wood & CR & B2ab(iii) \\
Dendrobium trullatum J.J.Wood \& A.L.Lamb & CR & B2ab(ii,iii) \\
Kipandiorchis jamirusii P.O'Byrne \& Gokusing & CR & B2ab(iii) \\
Paphiopedilum inamorii P.J.Cribb \& A.L.Lamb & CR & B2ab(iii) \\
Robiquetia odobenus P.O'Byrne \& Gokusing & CR & B2ab(iii) \\
Stichorkis hawchengii P.O'Byrne \& Gokusing & CR & A2c \\
Stichorkis lingulata (Ames \& C.Schweinf.) J.J.Wood & EN & B2ab(i,ii,iii,iv) \\
Thrixspermum caudatum P.O’Byrne \& Gokusing & EN & B2ab(i,ii,iii,iv) \\
Thrixspermum milneri P.O'Byrne \& Gokusing & CR & B2ab(iii) \\
Thrixspermum tubulatum P.O'Byrne & CR & B2ab(iii) \\
Trichoglottis tenuis Ames \& C.Schweinf. & EN & A2c
\end{tabular}

Note: Criterion A2c refers to a past reduction in population size, estimated as reduction in a decline in area of occupancy (AOO), extent of occurrence (EOO) and/or habitat quality. Criteria B2 refers to the extent of the geographic range measured as the area of occupancy, with (a) a severely fragmented or small number of locations and (b) a continuing decline in either the (i) extent of occurrence; (ii) area of occupancy; (iii) area, extent and/or quality of habitat; or (iv) number of locations or subpopulations (IUCN, 2020).

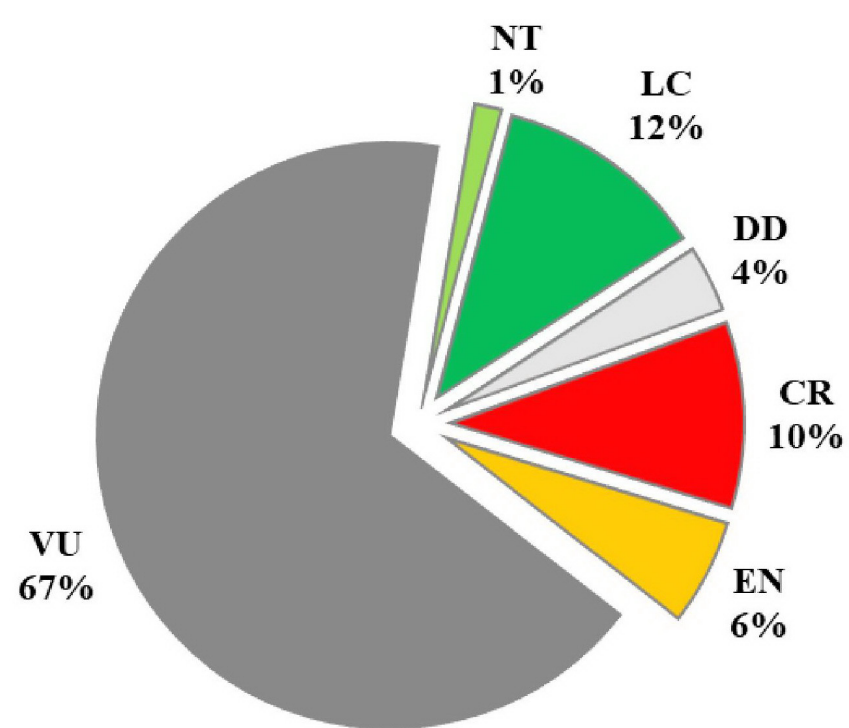

Fig. 2. Percentage of the Sabah endemic orchids within each of the IUCN threat categories. Designations: CR - Critically Endangered, EN - Endangered, VU - Vulnerable, NT - Near Threatened, LC - Less Concern, DD - Data Deficient.

\section{Species distribution model (SDM)}

We have produced species distribution models for 47 species. The AUCs for these models range from 0.714 to 0.998 (Electronic Supplement 2). The overlaid SDMs for the 45 models with an AUC higher than 0.8 shows that all species occur in the montane regions of western Sabah (Fig. 3). Areas with a high species richness of endemic orchids include Mount Kinabalu (45 species), Mount Tembuyuken (45 species), Mount
Alab (40 species), and Mount Trusmadi (28 species). Other areas that contained a range of Sabah endemic orchids were the ultramafic areas extending from central Sabah eastward towards Mount Silam, the Tawau Hill Park area in the southeast of Sabah and the Ulu Sipitang area in the southwest of Sabah (Fig. 3). With the exception of the Ulu Sipitang region and the midaltitude areas around Kinabalu and Crocker Range Parks, these areas are gazetted as TPAs.

\section{Discussion}

Of the 136 species evaluated in this study, 113, i.e. $83 \%$, are threatened (Fig. 2). Previous studies have reported that between 43.5 and $56.5 \%$ of orchids examined were threatened (Kull et al., 2016; Gale et al., 2018; Liu et al., 2020). These studies had either a broader geographical scope (Kull et al., 2016), examined the complete orchid flora of a region (Liu et al., 2020) or were a summary of global assessments (Gale et al., 2018). In contrast, we assessed species that were known to have narrow ranges and had a limited number of collections. As narrow range endemics tend to have higher threat levels and are more prone to extinction (Cribb et al., 2003; Swarts \& Dixon, 2009), this probably explains the higher percentage of threatened species in our study. With further assessments of the more widely distributed endemics, we envisage that the percentage of species listed as threatened should decline. 


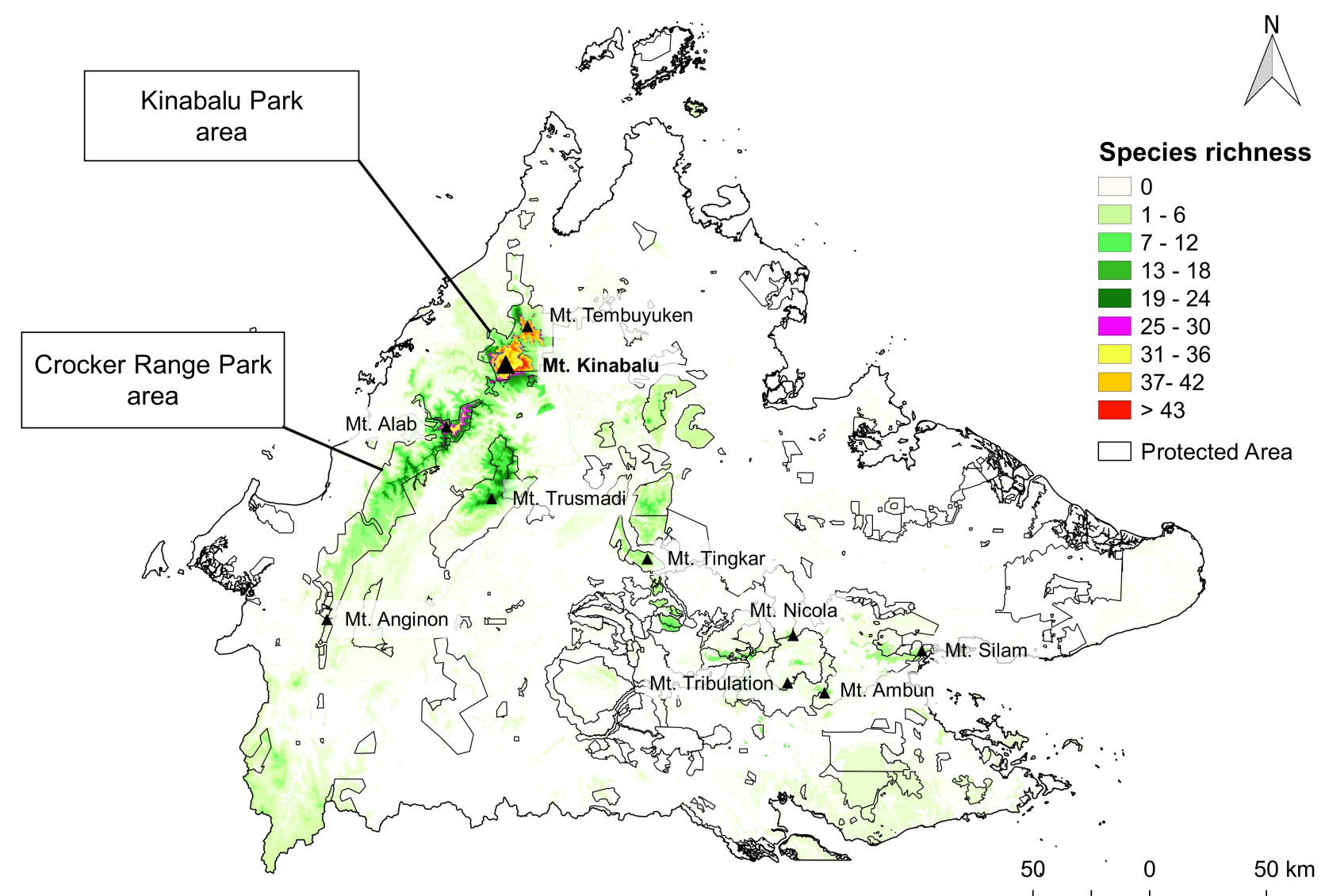

Fig. 3. Heatmap showing the species richness of Sabah endemic orchids on the basis of the 45 species with AUCs higher than 0.8 .

Despite having a higher overall percentage of threatened species, we found a lower percentage in the higher threat categories compared to the species currently listed on the IUCN Red List of Threatened Species (IUCN, 2020). Currently, of the ca. 1600 orchid species listed on the Red List, 34\% are listed as Critically Endangered or Endangered (IUCN, 2020). In our study, only $16 \%$ were assessed as either Critically Endangered or Endangered (Fig. 2). These differences could result from the different approaches. The IUCN data is a summary of the threat status of all orchids currently listed on the Red List, of the 542 species currently listed as CR or EN, 127 species are from Madagascar (IUCN, 2020), a region that has lost $44 \%$ of its forest cover in the last 60 years (Vieilledent et al., 2018). In contrast, most of the orchids examined in our study are species that are restricted to the montane areas of Sabah. The majority of this habitat is gazetted as TPAs, and has experienced a minimal habitat loss (Gaveau et al., 2014). So, while illegal collecting for the orchid trade is a potential threat to some of the species examined in this study, the loss of habit is negligible for most of them. However, we have not assessed how distribution might change due to climate change. Previous studies in Sabah suggested that narrow-range endemic restricted to the upper montane and subalpine forests of Sabah are at higher risk from climate change, than more widespread species (Maycock et al., 2011). Further study is required to investigate the potential impacts of climate change on the distribution of endemic orchids (Wraith \& Pickering, 2018).

The heat map produced from the stacked SDMs, shows that most of the areas with a high species richness fell within the existing TPAs (Fig. 3). All orchid species modelled occurred in the Kinabalu Park (Mount Kinabalu and Mount Tembuyuken) and the neighbouring Crocker Range Park (Mt. Alab). A few endemic orchid species were predicted to occur in the lowland areas. Previous studies also showed a higher species orchid richness at higher altitude, compared to lowland sites, with species richness then declining with the transition from upper montane to subalpine vegetation (Wood et al., 1993; Grytnes \& Beaman, 2006; Acharya et al., 2011; Zhang et al., 2015). This higher species richness is due to the heterogeneous habitat with various physical 
barriers on mountains that leads to a higher degree of isolation and results in a higher species diversification (Zhang et al., 2015). However, not all studies demonstrated a higher species richness of endemic orchids at higher altitudes (Acharya et al., 2011), as other factors, such as rainfall, temperature, habitat, soil and vegetation, contribute to endemic orchid distribution (Acharya et al., 2011; Hsu et al., 2011).

One limitation of our approach is that most of the highly threatened species had too few collections to model. Of the 22 species assessed as Critically Endangered or Endangered (Table 1), only two species (Bulbophyllum alatum J.J.Verm. and B. apheles J.J.Verm.) are included in the heatmap (Fig. 3). Most of the species assessed as Critically Endangered or Endangered were found outside of the TPA network. Six of the highly threatened species (Bulbophyllum alatum, B. apheles, B. scabrum J.J.Verm., B. sigmoideum Ames, Stichorkis lingulata (Ames \& C.Schweinf.) J.J.Wood, and Trichoglottis tenuis Ames \& C.Schweinf.) were collected from areas adjacent to the Kinabalu Park. The original collecting sites for these species have either been converted or are in the process of being converted to agricultural land. However, given the proximity to the Kinabalu Park, it is possible that populations may exist somewhere in the park. The Ulu Sipitang region is another hotspot for Critically Endangered or Endangered species, with Bulbophyllum porphyrotriche J.J.Verm., Dendrobium pseudoclavator J.J.Wood, Kipandiorchis jamirusii P.O'Byrne \& Gokusing, Paphiopedilum inamorii P.J.Cribb \& A.L.Lamb, Robiquetia odobenus P.O'Byrne \& Gokusing, and Thrixspermum milneri P.O'Byrne \& Gokusing collected from there. Both the mid-altitude areas adjacent to the Kinabalu Park and the Ulu Sipitang region were identified as potential Important Plant Areas located outside of the TPAs (Fig. 3). The areas adjacent to the Kinabalu and Crocker Range Park boundaries are mainly owned by local communities, so there is limited potential to expand the park boundaries (Wood et al., 1993). In contrast, most of the Ulu Sipitang area is gazetted as a production forest, under the jurisdiction of the Sabah Forestry Department. Therefore, we recommend the regazettement of this area as a TPA to increase plant protection in Sabah.

Several lowland endemics orchids were also assessed as Critically Endangered or Endangered
(Table 1). Four of these species (Stichorkis hawchengii P.O'Byrne \& Gokusing, Dendrobium cyrilianum P.O'Byrne, Gokusing \& J.J.Wood., Thrixspermum caudatum P.O'Byrne \& Gokusing, and Thrixspermum tubulatum P.O'Byrne) were recorded from the production forests around Kalabakan in southeastern Sabah. Dendrobium paitanense J.J.Wood is known from Sungai Paitan (River Paitan) in northeastern Sabah. These lowland areas are highly disturbed (Gaveau et al., 2014). And although some orchids are able to survive in disturbed habitats (Majit et al., 2014), it is uncertain how these species have been affected by these disturbances. Further field work is required to investigate whether these species are still extant in these areas.

In situ conservation is important to protect threatened species in their natural habitat. However, ex situ conservation is also appropriate for the Critically Endangered species, especially for those where there are limited or no in situ options available. We would like to suggest collaborations with any orchid garden in Sabah such as Kipandi Butterfly Farm, Poring Orchid Garden and Tenom Agriculture Park as well as local community for ex situ conservation, especially for threatened species. These orchids could potentially be reintroduced back into their natural habitats. Long-term monitoring of the endemic orchids and further collecting is required to gain a better understanding on population dynamics and threats, as well as to get living material for the development of ex situ conservation collections. While there are some on-going efforts in these areas, more extensive work is required to prevent species extinction.

\section{Conclusions}

In this study, we produced provisional IUCN Red List assessments for 136 species of orchids endemic to Sabah. Of these, $83 \%$ were assessed as being threatened. Our results highlight that the montane regions in western Sabah are a hotspot for diversity and conservation of endemic orchids. For most species, habitat loss was not the major threat as most occurred in the TPA network in Sabah. However, illegal collections for the horticulture trade and climate change are potential threats that need further monitoring.

While this is a desktop assessment, it is preferable to have a detailed assessment that include information on species habitat preferences, ecology, population structures and dy- 
namics, demography and threats (Kumar et al., 2001). These provisional assessments provide an overview of the threat status of the endemic orchids of Sabah. The information is being utilised by on-going conservation efforts in Sabah including the selection of new TPAs and developing species management plans to protect and conserve the most endangered endemic orchids in Sabah.

\section{Acknowledgements}

Special thanks to Datuk Anthony Lamb (Kota Kinabalu, Malaysia) and Linus Gokusing (Kipandi Butterfly Farm, Malaysia) for their help in data collection. We also thank Tenom Agriculture Park for data access. This research was funded by grants from the Ministry of Higher Education, Malaysia (FRGO414-STWN-1/2015), the Sabah Forestry Department's Conservation Trust fund and SEARRP (GLA0006).

\section{Supporting Information}

The list of endemic orchids used in the study and assessed according to IUCN guidelines (Electronic Supplement 1: Endemic orchids of Sabah used for analysis in the present study), and MaxEnt AUC values for each of orchid species used in SDM modelling (Electronic Supplement 2: List of species used in SDM modelling with MaxEnt AUC value) may be found in the Supporting Information here.

\section{References}

Acres B.D., Bowers R.P., Burrough P.A., Folland C.J., Kalsi M.S., Thomas P., Wright P.S. 1975. The soil of Sabah. Vol. 1: Classification and description. Land Resources Study 20. UK: Land Resources Division, Ministry of Overseas Development. $135 \mathrm{p}$.

Ashton P.S., Hall P. 1992. Comparisons of structure among mixed dipterocarp forests of north-western Borneo. Journal of Ecology 80(3): 459-481. DOI: 10.2307/2260691

Acharya K.P., Vetaas O.R., Birks H.J.B. 2011. Orchid species richness along Himalayan elevational gradients. Journal of Biogeography 38(9): 1821-1833. DOI: 10.1371/journal.pone.0142621

Bachman S., Moat J., Hill A.W., de la Torre J., Scott B. 2011. Supporting red list threat assessments with GeoCAT: Geospatial conservation assessment tool. ZooKeys 150: 117 126. DOI: $10.3897 /$ zookeys.150.2109

Ballantyne M., Pickering C. 2012. Ecotourism as a threatening process for wild orchids. Journal of Ecotourism 11(1): 34 47. DOI: 10.1080/14724049.2011.628398

Beaman R.S., Beaman J.H., Biun A., Nais J., Thomas A. 2003. Map of Mount Kinabalu. Map, scale: 1:50 000.

Brummitt N.A., Bachman S.P., Griffiths-Lee J., Lutz M., Moat J.F., Farjon A., Donaldson J.S., Hilton-Taylor C., Meagher T.R., Albuquerque S., Aletrari E., Andrews A.K., Atchison G., Baloch E., Barlozzini B., Brunazzi A., Carretero J., Celesti M., Chadburn H., Cianfoni E., Cockel C., Coldwell
V., Concetti B., Contu S., Crook V., Dyson P., Gardiner L., Ghanim N., Greene H., Groom A. et al. 2015. Green Plants in the Red: A Baseline Global Assessment for the IUCN Sampled Red List Index for Plants. PloS ONE 10(8): e0135152. DOI: 10.1371/journal.pone.0135152

Callmander M.W., Schatz G.E., Lowry P.P. 2005. IUCN Red List assessment and the Global Strategy for Plant Conservation: taxonomists must act now. Taxon 54(4): 1047 1050. DOI: $10.2307 / 25065491$

Chan C.L., Lamb A., Shim P.S., Wood J.J. 1994. Orchid of Borneo. Vol. 1. Kota Kinabalu: Sabah Society. 420 p.

Chapman A.D., Wieczorek J. (Eds.). 2006. Guide to Best Practices for Georeferencing. Copenhagen: Global Biodiversity Information Facility. 90 p.

Corlett R.T. 2016. Plant diversity in a changing world: Status, trends, and conservation needs. Plant Diversity 38(1): 10 16. DOI: 10.1016/j.pld.2016.01.001

Cribb P.J., Kell S.P., Dixon K.W., Barrett R.L. 2003. Orchid conservation: A global perspective. In: K.W. Dixon, S.P. Kell, R.L. Barrett, P.J. Cribb (Eds.): Orchid conservation. Kota Kinabalu: Natural History Publications. P. 1-24.

Ent A.V.D. 2013. Kinabalu. Kota Kinabalu: Natural History Publications (Borneo). P. 9-12.

Fay M.F. 2018. Orchid conservation: how can we meet the challenges in the twenty-first century? Botanical Studies 59(1): 16. DOI: $10.1186 / \mathrm{s} 40529-018-0232-\mathrm{z}$

Frazier C., Neville T., Giermakowski T., Racz G. 2004. The INRAM protocol for georeferencing Biological Museum Specimen Records. Version 1.3. Available from http://doi. org/10.5281/zenodo.3235003

Gale S.W., Fischer G.A., Cribb P.J., Fay M.F. 2018. Orchid conservation: bridging the gap between science and practice. Botanical Journal of the Linnean Society 186(4): 425-434. DOI: 10.1093/botlinnean/boy003

Gaveau D.L.A., Sloan S., Molidena E., Yaen H., Sheil D., Abram N.K., Ancrenaz M., Nasi R., Quinones M., Wielaard N., Meijaard E. 2014. Four decades of forest persistence, clearance and logging on Borneo. PLOS ONE 9(7): e101654. DOI: 10.1371/journal.pone.0101654

Giam X., Bradshaw C.J.A., Tan H.T.W., Sodhi N.S. 2010. Future habitat loss and the conservation of plant biodiversity. Biological Conservation 143(7): 1594-1602. DOI: 10.1016/j.biocon.2010.04.019

Grytnes J.A., Beaman J.H. 2006. Elevational species richness patterns for vascular plants on Mount Kinabalu, Borneo. Journal of Biogeography 33(10): 1838-1849. DOI: 10.1111/j.1365-2699.2006.01554.x

Hassler M., Rheinheimer J. 2020. Illustrated World Compendium of Orchids. World Plants. Available from https:// worldplants.webarchiv.kit.edu/orchids/

Hietz P. 1999. Diversity and Conservation of Epiphytes in a Changing Environment. In: Proceedings International Conference on Biodiversity and Bioresources: Conservation and Utilization. Phuket, Thailand. P. 1-11.

Hsu R.C.C., Tamis W.L.M., Raes N., Snoo G.R.D., Wolf J.H.D., Oostermeijer G., Lin S.H. 2011. Simulating climate change impacts on forests and associated vascular epiphytes in a subtropical island of East Asia. Diversity and Distributions 18(4): 334-347. DOI: 10.1111/j.1472-4642.2011.00819.x 
IUCN. 2020. The IUCN Red List of Threatened Species. Version 2020-1. Available from https://www.iucnredlist.org

IUCN Standards and Petitions Committee. 2019. Guidelines for Using the IUCN Red List Categories and Criteria. Version 14. Available from http://www.iucnredlist.org/documents/ RedListGuidelines.pdf

Jackson P.W., Kennedy K. 2009. The global strategy for plant conservation: a challenge and opportunity for the international community. Trends in Plant Science 14(11): 578 580. DOI: 10.1016/j.tplants.2009.08.011

Kull T., Selgis U., Pecica M.V., Metsare M., Ilves A., Tali K., Sepp K., Kull K., Shefferson R.P. 2016. Factors influencing IUCN threat levels to orchids across Europe on the basis of national red lists. Ecology and Evolution 6(17): 6245-6265. DOI: 10.1002/ece3.2363

Kumar C.S., Shetty B.V., Bennet S.S.R., Rao T.A., Molur S., Walker S. (Eds.). 2001. Endemic Orchids of the Western Ghats - Conservation Assessment and Management Plan (C.A.M.P.) Workshop. Coimbatore, India: Wildlife Information Liaison Development (WILD) Society and Zoo Outreach Organisation. $195 \mathrm{p}$.

Lamb A. 1991a. The conservation of orchids in Sabah. In: V.H. Heywood, P.W. Jackson (Eds.): Tropical Botanic Gardens: Their Role in Conservation and Development. London: Academic Press. P. 307-326.

Lamb A. 1991b. Orchids of Sabah and Sarawak. In: R. Kiew (Ed.): The state of conservation in Malaysia. Kuala Lumpur: Malayan Nature Society. P. 78-89.

Liu H., Liu Z., Jin X., Gao J., Chen Y., Liu Q., Zhang D.Y. 2020. Assessing conservation efforts against threats to wild orchids in China. Biological Conservation 243: 108484. DOI: $10.1016 /$ j.biocon.2020.108484

Majit H.F., Lamb A., Miadin R., Suleiman M. 2014. The wild orchids of Crocker range national park, Sabah, Malaysia. Malayan Nature Journal 66(4): 440-462.

Marsh C.W, Greer A.G. 1992. Forest land-use in Sabah, Malaysia: an introduction to Danum Valley. Philosophical Transactions - Royal Society of London B 335(1275): 331-339. DOI: $10.1098 /$ rstb.1992.0025

Maycock C.R., Majapun R., Khoo E., Pereira J., Sugau J., Burslem D.F.R.P. 2011. The potential impacts of climate change on the distribution of Nepenthes and dipterocarps of the Trus Madi Forest Reserve. In: R. Sulaiman, A. Mohammad, V.K. Chey (Eds.): Conservation of Biodiversity in Trus Madi Forest Reserve. Sandakan: Sabah Forestry Department. P. 95-104.

Maycock C.R., Kettle C.J., Khoo E., Pereira J.T., Sugau J.B., Nilus R., Ong R.C., Amaludin N.A., Newman M.F., Burslem F.R.P. 2012. A revised conservation assessment of Dipterocarps in Sabah. Biotropica 44(5): 649-657. DOI: 10.1111/j.1744-7429.2011.00852.x

Merow C., Smith M.J., Silander J.A. 2013. A practical guide to MaxEnt for modeling species' distributions: what it does, and why inputs and settings matter. Ecography 36(10): 1058-1069. DOI: 10.1111/j.1600-0587.2013.07872.x

O'Byrne P. 2016. Thrixspermum in Borneo; 24 New and Old Species. Malesian Orchid Journal 18: 5-74.
Proctor J. 2003. Vegetation and soil and plant chemistry on ultramafic rocks in the tropical Far East. Perspectives in Plant Ecology, Evolution and Systematics 6(1-2): 105 124. DOI: $10.1078 / 1433-8319-00045$

Sabah Forestry Department. 2004. New Classification - Sabah. In: Conservation Areas Information and Monitoring Systems. Available from http://ww2.sabah.gov.my/htan_cai$\mathrm{ms} /$ Vegetation/new\%20classification.htm

Swarts N.D., Dixon K.W. 2009. Terrestrial orchid conservation in the age of extinction. Annal of Botany 104(3): 543-556. DOI: $10.1093 / \mathrm{aob} / \mathrm{mcp} 025$

Tangah J., Wong K.M. 1995. A Sabah gazetteer. Sandakan: Sabah Forestry Department. $125 \mathrm{p}$.

Vermeulen J.J. 1994. Orchids of Borneo. Bulbophyllum. Vol. 2. Kota Kinabalu, Kew: The Sabah Society and the Royal Botanic Gardens. 352 p.

Vermeulen J.J., Lamb A. 2011. Endangered even before formally described: Bulbophyllum kubahense n.sp., a beautiful and assumedly narrowly endemic orchid from Borneo. Plant Systematics and Evolution 292(1): 51-53. DOI: 10.1007/s00606-010-0414-y

Vieilledent G., Grinand C., Rakotomalala F.A., Ranaivosoa R., Rakotoarijaona J.R., Allnutt T.F., Achard F. 2018. Combining global tree cover loss data with historical national forest cover maps to look at six decades of deforestation and forest fragmentation in Madagascar. Biological Conservation 222: 189-197. DOI: 10.1016/j.biocon.2018.04.008

Williams S.H., Scriven S.A., Burslem D.F.R.P., Hill J.K., Reynolds G., Agama A.L., Kugan F., Maycock C.R., Khoo E., Hastie A.Y., Sugau J.B., Nilus R., Pereira J.T., Tsen S.L., Lee L.Y., Juiling S., Hodgson J.A., Cole L.E., Asner G.P., Evans L.J., Brodie J.F. 2020. Incorporating connectivity into conservation planning for the optimal representation of multiple species and ecosystem services. Conservation Biology 34(4): 934-942. DOI: 10.1111/cobi.13450

Wood J.J. 1997. Orchids of Borneo. Vol. 3. Kota Kinabalu, Kew: The Sabah Society and Royal Botanic Gardens. 299 p.

Wood J.J. 2003. Orchids of Borneo. Vol. 4. Kota Kinabalu, Kew: The Sabah Society and Royal Botanic Gardens. 326 p.

Wood J.J. 2010. Three New Species of Dendrobium from Sabah. Malesian Orchid Journal 5: 119-121.

Wood J.J., Cribb P.J. 1994. A checklist of the orchids of Borneo. London: Royal Botanic Gardens, Kew. 421 p.

Wood J.J., Beaman R.S., Beaman J.H. 1993. The Plants of Mount Kinabalu: Orchids. Vol. 2. Kota Kinabalu: Natural History Publications (Borneo). $410 \mathrm{p}$.

Wood J.J., Beaman T.E., Lamb A., Lun C.C., Beaman J. H. 2011. The orchids of Mount Kinabalu. Vol. 2. Kota Kinabalu: Natural History Publications (Borneo). 1184 p.

Wraith J., Pickering C. 2018. Quantifying anthropogenic threats to orchids using the IUCN Red List. Ambio 47(3): 307 317. DOI: 10.1007/s13280-017-0964-0

Zhang Z., Yan Y., Tian Y., Li J., He J.S., Tang Z. 2015. Distribution and conservation of orchid species richness in China. Biological Conservation 181: 64-72. DOI: 10.1016/j.biocon.2014.10.026 


\title{
ОЦЕНКА ПРИРОДООХРАННОГО СТАТУСА И ПРОСТРАНСТВЕННОЕ
} РАСПРЕДЕЛЕНИЕ ЭНДЕМИЧНЫХ ОРХИДЕЙ В САБАХЕ (БОРНЕО)

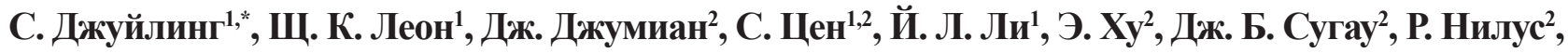 \\ Дж. Т. Перейра ${ }^{2}$, А. Дамит ${ }^{2}$, С. Танггараджу ${ }^{1}$, П. О’Бирн ${ }^{3, \dagger}$, С. Сумайл ${ }^{4}$, Х. Муджих ${ }^{4}$, К. Р. Мэйкок ${ }^{1}$ \\ ${ }^{1}$ Университет Малайзии Сабах, Малайзия \\ e-mail:*suzikajuiling@gmail.com,tsensandy@gmail.com,yewleung@gmail.com, \\ bs14161036@alum.ums.edu.my,colinr@ums.edu.my \\ 2Департамент лесного хозяйства Сабаха, Малайзия \\ e-mail:gmirus4@gmail.com,biodipterocarp@gmail.com,john.sugau@sabah.gov.my, \\ rnilus70@gmail.com,joan.pereira18@gmail.com,Alviana.Damit@sabah.gov.my \\ ${ }^{3}$ Сабах, Малайзия \\ e-mail: oberonia@gmail.com \\ ${ }^{4}$ Парки Сабаха, Малайзия \\ e-mail:skybyn@gmail.com,hanrymujih@gmail.com
}

\begin{abstract}
Орхидеи являются одними из наиболее угрожаемых растений в результате утраты местообитаний и их незаконного сбора для садоводческих нужд. Сабах является центром разнообразия орхидей, насчитывая около 1300 видов, в т.ч. 250 таксонов орхидей-эндемиков Сабаха. В этом исследовании мы провели оценку 136 эндемичных видов согласно критериям Красного списка МСОП и использовали метод максимальной энтропии (MaxEnt) для разработки моделей распределения видов для 47 орхидей. Модели распространения видов были разработаны с использованием данных только о присутствии и шести экологических предикторов. Точность моделей оценивалась с использованием площади под кривой (AUC) и моделей со значением AUC более 0.8, сложенных вместе для создания карты пространственного распределения видового богатства. Мы обнаружили, что 83\% видов находятся под угрозой исчезновения, из которых 14 видов были оценены как находящиеся на грани полного исчезновения (Critically Endangered), восемь видов - как исчезающие (Endangered), a 93 вида - как уязвимые (Vulnerable). Карта пространственного распределения видового богатства орхидей показала, что все виды обитают в сети полностью охраняемых территорий в Западном Сабахе. На данной карте выделяются среднегорные районы, примыкающие к Кинабалу парку и Крокер-Рендж парку и регионам Улу-Сипитанг, как районы с высоким видовым богатством, находящиеся за пределами сети полностью охраняемых территорий. Эти районы также важны для сохранения большинства видов, оцененных как находящиеся на грани полного исчезновения и исчезающие. Необходимы срочные природоохранные меры для предотвращения исчезновения этих видов. Результаты настоящей работы будут использованы как часть интенсивного плана действий по сохранению находящихся под угрозой исчезновения эндемичных орхидей Сабаха и использованы для выделения важных ботанических территорий, которые в настоящее время не входят в существующую сеть полностью охраняемых территорий.
\end{abstract}

Ключевые слова: MaxEnt, Orchidaceae, видовое богатство, моделирование распространения видов, незаконный сбор, особо охраняемая природная территория, статус Красного списка МСОП, утрата местообитания 